\title{
Original article: \\ Effects of an eight-week lumbar stabilization exercise programme on selected variables of patients with chronic low back pain \\ Ademola O. Abass ${ }^{1}$, Abiola R. Alli², Oladapo M. Olagbegi ${ }^{3}$, Candice J. Christie ${ }^{4}$ and Samuel O. Bolarinde ${ }^{5}$
}

\begin{abstract}
:
Background: Lumbar stabilisation exercise has been shown to reduce pain and disability in patients with low back pain but information on its potential benefits in term of back muscle endurance is scarce. Objective: This study was aimed at investigating the effects of augmenting conventional physiotherapy with lumbar stabilization exercises on selected variables of patients with non-specific chronic low back pain (NSCLBP). Methods: Forty individuals with NSCLBP aged 20-60 years were assigned to one of experimental or control groups (20 in each). The experimental group had lumbar stabilisation exercises in addition to conventional therapy (transcutaneous electrical nerve stimulator and infrared) which was the only treatment for the control group. Both groups were treated thrice weekly. Participants' pain intensity, disability index, kinesiophobia level and back muscle endurance were evaluated at baseline and after 8 weeks. Results: There was significant reduction in pain intensity (experimental: 6.74 \pm 1.37 ; $3.48 \pm 1.09$; control: $6.57 \pm 1.40 ; 2.96 \pm 1.13$ ) and disability index (experimental: $46.60 \pm 16.67$; 26.55 \pm 14.78 ; control: $32.10 \pm 16.16 ; 24.60 \pm 15.27)$ and increase in back muscle endurance (experimental: $11.05 \pm 8.39 ; 14.30 \pm 19.24 \mathrm{~s}$; control: $10.85 \pm 9.79 ; 13.90 \pm 11.63 \mathrm{~s}$ ) for both groups. Experimental group had significantly greater reduction $(\mathrm{p}<0.05)$ in disability index than the controls $(p=0.048)$. Conclusion: Augmenting conventional physiotherapy with lumbar stabilisation exercises achieved better reduction in disability than conventional therapy alone in patients with NSCLBP.
\end{abstract}

$\underline{\text { Keywords: }}$ Endurance; low back pain; fear of movement; function; lumbar stabilization

Bangladesh Journal of Medical Science Vol. 19 No. 03 July'20. Page : 467-474 DOI: https://doi.org/10.3329/bjms.v19i3.45864

\section{Introduction}

Low back pain (LBP) is a common problem which affects the majority of adults at least once in their lifetime. ${ }^{1}$ It is a health challenge of global concern and is as common as a headache affecting all age groups and races. ${ }^{1,2}$ It is pain and discomfort localised below the costal margin and above the inferior gluteal folds with or without leg pain (sciatica). ${ }^{3,4}$ An acute episode of LBP usually resolves over a period of two to four weeks for $90 \%$ of patients, however, the recurrence rate of an acute episode is high, especially within the following 12 months. ${ }^{5}$ This recurrence leads to chronic low back pain (CLBP) which is associated with high economic and health care burden costs. ${ }^{5}$

The lifetime and one year prevalence of LBP is about $60-80 \%$ and $34 \%$ respectively. ${ }^{6,7}$ Men have a higher risk for recurrence than women and the highest recurrence has been reported among individuals between $25-44$ years. ${ }^{7}$ Low back pain is one of the most common musculoskeletal problems that bring

1. Ademola O. Abass, Department of Human Kinetics and Physical Education, Faculty of Education, University of Ibadan, Nigeria

2. Abiola R. Alli, Department of Physiotherapy, Federal Medical Centre, Owo, Ondo State, Nigeria.

3. Oladapo M. Olagbegi, Discipline of Physiotherapy, School of Health Sciences, University of Kwa ZuluNatal, Durban, South Africa.

4. Candice J. Christie, Department of Human Kinetics and Kinetics and Ergonomics, Rhodes University, Grahamstown, South Africa.

5. Samuel O. Bolarinde, Department of Physiotherapy, Federal Medical Centre, Owo, Ondo State, Nigeria.

Correspondence to: Dr. Oladapo Michael Olagbegi, Discipline of Physiotherapy, School of Health Sciences, University of Kwa Zulu-Natal, Durban, South Africa. E-mail: olagbegioladapo@yahoo.com 
patients to the hospital ${ }^{8}$ and the third leading cause of disability and associated absenteeism from work. ${ }^{7}$

Low back pain is strongly associated with high level of disability which implies a significant inability to engage in meaningful and necessary activities of daily living. ${ }^{9}$ Clinical studies have also suggested that consideration of excessively negative orientation toward pain (pain catastrophizing) and kinesiophobia are important in managing chronic low back pain and associated disability. ${ }^{10,11,12}$ Kinesiophobia describes fear of movement and re-injury; ${ }^{11}$ it is an irrational and debilitating fear of physical movement and activity resulting from a feeling of vulnerability to painful injury or re -injury. ${ }^{13}$ Individuals who catastrophize pain are likely to become fearful of pain, and this results in pain-related fear which is associated with avoidance behaviors, particularly, the avoidance of movement and physical activity. ${ }^{12}$ The individual may withdraw from activities of daily living and family. ${ }^{12}$ Moreover, pain-related fearis reportedly associated with increased bodily awareness and pain hypervigilance. Pain hypervigilance, in addition to depression and disuse, are associated with increased pain levels and experience. ${ }^{12}$

Studies have reported significant decrease in back extensor muscle endurance in patients with LBP; ${ }^{14,15}$ these are postural muscles that aid in maintaining the upright standing posture and controlling lumbar forward bending. It is thought that decreased back muscle endurance causes muscular fatigue and consequently overloads soft tissue and the passive structures of the lumbar spine, resulting in low back pain. ${ }^{16}$ Reduced back extensor muscle endurance has been identified as an important risk factor for LBP ${ }^{17}$ and there is an inverse relationship between pain intensity and static back extensors endurance among patients with long-term mechanical LBP. ${ }^{18}$ Decreased back muscle endurance could be either a cause or consequence of LBP. ${ }^{19,20}$ Hence, assessment of back muscle endurance is crucial in the prediction, prevention and rehabilitation of LBP.

Lumbar stabilisation exercises (LSE) and other exercise programs fall within a paradigm of therapeutic exercises used in treatment of LBP. ${ }^{21}$ They are exercises aimed at improving the activation patterns of trunk muscles, in order to relieve lumbar pain and limitation through trunk muscle contraction. 21,22 This exercise approach has become very popular as opposed to passive modalities such as; ultrasound, transcutaneous electrical nerve stimulation (TENS), short-wave diathermy, and massage that only aim to reduce symptoms but do not in any way alleviate a patient's predisposition to recurrent episode. The vulnerability of LBP recurrence is not completely understood $^{23,24}$ however, instability of the lumbar motion is considered an important cause. ${ }^{25,26}$

Richardson and Jull ${ }^{26}$ submitted that core stability exercises can be used to reactivate and improve the motor control of the multifidus (a core spinal stabilizer), and therefore prevent further episodes of LBP. Kim et al ${ }^{27}$ reported that an eight-week LSE increased paraspinal muscle strength and the crosssectional areas of multifidus psoa major muscles in patients with degenerative disc disease. Long term LSE, as a single therapy or in combination with other treatments, can reduce pain and disability in CLBP and prevent a recurrent pain episode. ${ }^{28,29}$

Although physiotherapy research has made headway with regard to classification of patients with LBP into treatment-based homogeneous subgroups, evidence was also found in support of LSE's effectiveness in decreasing pain and improving function even in a heterogeneous group of patients with CLBP. ${ }^{29}$ França et $\mathrm{al}^{30}$ reported that a six-week LSE resulted in reductions in pain and functional disorder index by 0.06 points and 1.80 points respectively and they concluded that stabilisation exercises were a beneficial therapy. The work of Kumar ${ }^{31}$ also showed that LSE are effective for patients with symptomatic lumbar segmental instability.

In spite of all available evidence in support of LSE in the management of non-specific chronic low back pain (NSCLBP), there is still dearth of studies on whether recovered cross-sectional area of the multifidus muscle following lumbar stabilisation exercises resulted in improved endurance of back muscles. Information on the efficacy of LSE among Nigerians with NSCLBP also appears sparse. Therefore the purpose of this study was to investigate the effects of an 8-week lumbar stabilisation exercise training programme on pain intensity, disability, kinesiophobia and back muscle endurance among individuals with low back pain

\section{Methods}

A quasi-experimental study involving patients with non-specific chronic low back pain (NSLBP) was performed. The participants gave their written informed consent once the trial procedure was explained to them. They were patients diagnosed of mild to moderate non-specific low back pain(of at least 12 weeks duration) by the orthopaedic 
surgeon and/or family physician. The participants were also attending an out-patient Physiotherapy at the Department of Physiotherapy, FMC, Owo, Ondo State, Nigeria. Individuals with specific spine pathology (such as tuberculosis spine, spinal fracture and tumour), those with co-morbidities such as infection and referred pain from internal organs were excluded from the study. Pregnant women with low back pain and patients with LBP who were 18 years or younger were also excluded from the study.

Participants were allotted numbers once they became available and assigned to one of experimental or the control groups.

\section{Intervention}

\section{Experimental Group}

Participants received Infrared radiation (using BL220 Infrared lamp, MT03009201 model) for 15 minutes, Transcutaneous Electrical Nerve stimulation (using model DX66053, pain modulation mode) for 10 minutes and back education in form of counselling on recurrence and prevention. All participants were given a copy of the back pain prevention instructional booklet by Odebiyi ${ }^{32}$ for home guide.

The lumbar stabilisation exercise protocol was taught in three phases:

Phase 1: Development of the perception of isolated isometric specific contraction of stabilizing muscles; the phase involved teaching of isometric contraction of tranversus abdominis and multifidus muscles

Phase 2: Exercises in closed chain, low velocity and low load; the purpose was to maintain local muscle synergy contraction, while gradually progressing load cues through the body using weight bearing closed chain exercises.

Phase 3: Exercises in open chain, low velocity and high load; this was aimed at continued maintenance of local segmental control while load is added through open kinetic chain movement of adjacent segments.

The protocol and progression for lumbar stabilisation exercises as employed in this study is summarized in Table 1.

Table 1: Summary of lumbar stabilisation exercise training protocol

\begin{tabular}{|c|c|c|c|c|c|}
\hline Week & Type & Intensity & $\begin{array}{c}\text { Work/relief ratio } \\
\text { (2:1) }\end{array}$ & Duration & Frequency \\
\hline \multirow[t]{2}{*}{ Week 1} & $\begin{array}{l}\text { Isometric contraction of } \\
\text { abdominal muscles }\end{array}$ & $\begin{array}{l}\text { Contraction held for } 10 \operatorname{secs}(10 \\
\text { repetitions) }\end{array}$ & $\begin{array}{l}5 \text { secs. between } \\
\text { repetitions }\end{array}$ & $15 \mathrm{mins}$ & Twice weekly \\
\hline & $\begin{array}{l}\text { Isometric contraction of } \\
\text { mutifidus (supine/prone) }\end{array}$ & $\begin{array}{l}\text { Contraction held for } 10 \text { secs (10 } \\
\text { repetitions) }\end{array}$ & & $15 \mathrm{mins}$ & Twice weekly \\
\hline \multirow[b]{2}{*}{ Week 2} & $\begin{array}{l}\text { Isometric contraction } \\
\text { abdominal }\end{array}$ & $\begin{array}{l}\text { Contraction held for } 10 \operatorname{secs}(10 \\
\text { repetitions) }\end{array}$ & $\begin{array}{l}5 \text { secs. between } \\
\text { repetition }\end{array}$ & $15 \mathrm{mins}$ & Twice weekly \\
\hline & $\begin{array}{l}\text { Isometric contraction } \\
\text { multifidus (sitting position) }\end{array}$ & $\begin{array}{l}\text { Contraction held for } 10 \text { secs (10 } \\
\text { repetitions) }\end{array}$ & & $15 \mathrm{mins}$ & Twice weekly \\
\hline Week 3 & $\begin{array}{l}\text { Isometric contraction of } \\
\text { abdominal in bridge prone } \\
\text { position with spine straight }\end{array}$ & $\begin{array}{l}\text { Contraction held for } 10 \operatorname{secs}(20 \\
\text { repetitions) }\end{array}$ & $\begin{array}{l}5 \text { secs between } \\
\text { repetition }\end{array}$ & $15 \mathrm{mins}$ & Twice weekly \\
\hline Week 4 & $\begin{array}{c}\text { Isometric contraction of } \\
\text { abdominal in lateral bridge } \\
\text { in prone position with spine } \\
\text { straight }\end{array}$ & $\begin{array}{l}\text { Contraction held for } 10 \operatorname{secs}(20 \\
\text { repetitions) }\end{array}$ & $\begin{array}{l}5 \text { secs between } \\
\text { repetition }\end{array}$ & $30 \mathrm{mins}$ & Twice weekly \\
\hline Week 5 & $\begin{array}{c}\text { Isometric contraction of } \\
\text { abdominal in bridge with spine } \\
\text { straight }\end{array}$ & $\begin{array}{l}\text { Contraction held for } 10 \operatorname{secs}(20 \\
\text { repetitions) }\end{array}$ & $\begin{array}{l}5 \text { secs between } \\
\text { repetitions }\end{array}$ & $30 \mathrm{mins}$ & Twice weekly \\
\hline week 6 & $\begin{array}{l}\text { Isometric contraction of } \\
\text { abdominal in four points } \\
\text { kneeling }\end{array}$ & $\begin{array}{l}\text { Contraction held for } 20 \operatorname{secs}(10 \\
\text { repetitions) }\end{array}$ & $\begin{array}{l}5 \text { secs between } \\
\text { repetitions }\end{array}$ & $35 \mathrm{mins}$ & 2 times/week \\
\hline Week 7 & $\begin{array}{c}\text { Isometric contraction of } \\
\text { abdominal with alternate arm } \\
\text { and leg raise }\end{array}$ & $\begin{array}{l}\text { Contraction held for } 20 \text { secs ( } 20 \\
\text { repetitions) }\end{array}$ & $\begin{array}{l}5 \text { secs between } \\
\text { repetitions }\end{array}$ & $35 \mathrm{mins}$ & Twice weekly \\
\hline Week 8 & $\begin{array}{l}\text { Isometric contraction of } \\
\text { abdominal muscle with } \\
\text { alternate arm/leg raise }\end{array}$ & $\begin{array}{c}\text { Contraction was held for } 20 \operatorname{secs}(20 \\
\text { repetitions) }\end{array}$ & $\begin{array}{l}5 \text { secs between } \\
\text { repetitions }\end{array}$ & $35 \mathrm{mins}$ & Twice weekly \\
\hline
\end{tabular}




\section{Control group}

Control group participants received all the treatments given to the experimental group except lumbar stabilisation exercises. Participants were treated twice weekly.

\section{Assessments}

\section{Pain Intensity:}

The Visual Analogue Scale (VAS) was used to assess participants' pain intensity. They were instructed to mark the point that corresponded to the intensity of their present pain on the VAS. The point marked was measured with a ruler and recorded as pain intensity (PI). ${ }^{33}$

\section{Kinesiophobia}

The Tampa Scale of Kinesiophobia (TSK) Questionnaire was administered on the participants to assess their kinesiophobia level (fear of movement). The TSK Questionnaire consists of 17 statements capturing the idea that pain is a signal for re-injury because of physical inactivity or certain movements. Participants completed the questionnaire and indicated their level of agreement on a 4-point rating scale. The possible scores ranged from 4 (low fear of movement) to 68 (high fear of movement). Back et $\mathrm{al}^{34}$ reported a good test-retest reliability of 0.78 for TSK Questionnaire.

\section{Disability Index}

Participants' disability index was evaluated using the Revised Oswestry Disability Questionnaire (RODQ). It's a ten-section self-administered questionnaire with six levels each, assessing the limitation of various activities of daily living. The range of possible scores ranges from 0 (best health) to 100 (worst health). The total was then divided by total score and expressed in percentage to produce disability index. ${ }^{35}$

\section{Back muscle endurance}

The prone double straight-leg raise test was used to assess participants' back muscle endurance. The participant lay on the plinth in prone-lying position, hips extended, with the hands underneath the forehead and the arms perpendicular to the body. The participant was then instructed to raise both legs until knee clearance was achieved. The researcher monitored knee clearance by sliding one hand under the thighs. The time taken by participant to maintain knee clearance monitored with a stopwatch (Quartz, USA) was recorded in seconds as back muscle endurance. ${ }^{36}$

\section{Data Analysis}

The data were analysed using Statistical Package for Social Sciences(SPSS) Version 20.0.A minimum sample size of 34 (17 per group) was estimated for the study at $\alpha=0.05$, power $=80 \%$ and effect size $=$ 0.8 using the Cohen's table ${ }^{37}$. Assuming attrition rate of $10 \%$, a total of 40 participants were recruited for the study. A large effect size of was obtained from an initial pilot study conducted.

Shapiro Wilk test performed to test for normality showed that the data for the four outcomes tested in this study are normally distributed.The data was summarized by using descriptive statistics of mean, standard deviation and 95\% confidence intervals. Independent and paired t-tests were used for between and within group respectively for comparisons of participants' variables. Since the experimental group had significantly higher disability index scores than the control group at baseline, Analysis of Covariance (ANCOVA) was used to compare the effects of the two interventions used in this study adjusting for baseline values of all tested measures (covariates). Statistical significance was set at 0.05

Ethical clearance: The study was approved by the Health Research Ethics Committee of the Federal Medical Centre (FMC), Owo, Nigeria (Ref no: FMC/ OW/380/VOL.XV/11).

\section{Results}

All forty participants completed the protocol. The participants' demographic and baseline selected disease-related variables are presented in table 2 .

Table 2: Participants' demographic and baseline selected disease-related variables

\begin{tabular}{lllll}
\hline \multicolumn{5}{c}{ Groups } \\
Variables & $\begin{array}{l}\text { Experimental } \\
\text { Mean } \pm \text { SD }\end{array}$ & $\begin{array}{l}\text { Control } \\
\text { Mean } \pm \text { SD }\end{array}$ & t & p-value \\
\hline Age (years) & $48.15 \pm 9.02$ & $53.1 \pm 7.91$ & 1.845 & 0.073 \\
Weight (kg) & $73.25 \pm 3.54$ & $71.45 \pm 2.73$ & 1.367 & 0.182 \\
Height (cm) & $165.75 \pm 4.56$ & $164.4 \pm 1.71$ & 0.678 & 0.500 \\
BMI (kgm $\left.{ }^{-2}\right)$ & $29.51 \pm 15.99$ & $26.57 \pm 5.00$ & 0.787 & 0.436 \\
PI & $6.74 \pm 1.37$ & $6.57 \pm 1.40$ & 0.387 & 0.701 \\
DI & $46.60 \pm 16.67$ & $32.10 \pm 16.16$ & 2.793 & $0.008^{*}$ \\
KIN & $40.55 \pm 5.61$ & $42.10 \pm 4.23$ & -0.986 & 0.330 \\
BME (s) & $11.05 \pm 8.39$ & $10.85 \pm 9.79$ & 0.069 & 0.945 \\
\hline
\end{tabular}

*denotes significance at $\mathrm{p} \leq 0.05$

PI - pain intensity scores, DI - disability index scores, KIN- kinesiophobia scores, BME - back muscle endurance 
Experimental (6 male, 14 female) and control (5 male, 15 female) groups were comparable in their demographics. The experimental group had significantly higher $(\mathrm{p}<0.05)$ mean disability index scores than control group $(\mathrm{p}=0.008)$ but the groups were not significantly different on the other three measures at baseline. Table 3 displays within-group comparison of the each of the two groups, there were significant reductions in pain intensity scores (experimental: $6.74 \pm 1.37 ; 3.48 \pm 1.09$; control: $6.57 \pm 1.40 ; 2.96 \pm 1.13)$ and disability index scores (experimental: $46.60 \pm 16.67 ; 26.55 \pm 14.78$; control: $32.10 \pm 16.16 ; 24.60 \pm 15.27)$ and increase in back muscle endurance (experimental: 11.05 8.39; $14.30 \pm 19.24 \mathrm{~s}$; control: $10.85 \pm 9.79 ; 13.90 \pm 11.63 \mathrm{~s}$ ) between baseline and week 8 . Kinesiophobia scores did not significantly improve for both groups (experimental: $\mathrm{p}=0.835$; control: $\mathrm{p}=0.746$ ).

Table 3: Within-group comparison of experimental and control groups across baseline and the end of $8^{\text {th }}$ week of study

\begin{tabular}{|c|c|c|c|c|}
\hline \multirow{3}{*}{ Variables } & \multicolumn{4}{|c|}{ Experimental } \\
\hline & \multirow{2}{*}{$\begin{array}{l}\text { Baseline } \\
\text { Mean } \pm \text { SD }\end{array}$} & \multicolumn{3}{|l|}{ Week 8} \\
\hline & & Mean \pm SD & t-value & p-value \\
\hline PI & $6.74 \pm 1.37$ & $3.48 \pm 1.09$ & -8.297 & $<0.001^{*}$ \\
\hline DI & $46.60 \pm 16.67$ & $26.55 \pm 14.78$ & 4.856 & $<0.001^{*}$ \\
\hline KIN & $40.55 \pm 5.61$ & $40.78 \pm 4.86$ & -0.149 & 0.835 \\
\hline \multirow[t]{2}{*}{ BME (s) } & $11.05 \pm 8.39$ & $14.30 \pm 19.24$ & 5.175 & $0.001 *$ \\
\hline & Group & Control & & \\
\hline PI & $6.57 \pm 1.40$ & $2.96 \pm 1.13$ & 15.563 & $0.001 *$ \\
\hline DI & $32.10 \pm 16.16$ & $24.60 \pm 15.27$ & 5.252 & $0.003 *$ \\
\hline KIN & $42.10 \pm 4.23$ & $41.70 \pm 4.17$ & 0.1212 & 0.746 \\
\hline BME (s) & $10.85 \pm 9.79$ & $13.90 \pm 11.63$ & 4.018 & $<0.001 *$ \\
\hline
\end{tabular}

Key:

*denotes significance at $\mathrm{p} \leq 0.05$

PI - pain intensity scores, DI - disability index scores, KIN- kinesiophobia scores, BME - back muscle endurance

A between-group comparison computed with baseline values as covariates is presented in Table 4; the experimental group had a significantly greater reduction in disability than the controls $(\mathrm{p}=0.048)$, effect size: 0.102 ) at the end of $8^{\text {th }}$ week. The groups' baseline difference in disability was adjusted for by using baseline values as covariates.
Table 4: One-way ANCOVA comparison of the changes in the groups' parameters (using baseline values as covariates)

\begin{tabular}{|c|c|c|c|c|c|}
\hline Variable & Group & $\begin{array}{c}\text { Baseline } \\
\text { Mean } \pm \text { SD } \\
(95 \% \text { CI })\end{array}$ & $\begin{array}{c}\text { Week } 8 \\
\text { Mean } \pm \text { SD } \\
(95 \% \text { CI })\end{array}$ & $\mathrm{p}$-value & $\begin{array}{c}\text { Partial Eta } \\
\text { Square }\end{array}$ \\
\hline PI & Experimental & $\begin{array}{c}6.74 \pm 1.37 \\
(6.09-7.38)\end{array}$ & $\begin{array}{c}3.48 \pm 1.09 \\
(2.92-5.96)\end{array}$ & 0.082 & 0.082 \\
\hline \multirow{3}{*}{ DI } & Control & $\begin{array}{c}6.57 \pm 1.40 \\
(5.91-7.21)\end{array}$ & $\begin{array}{l}2.96 \pm 1.13 \\
(2.43-3.49)\end{array}$ & \multirow{3}{*}{$0.048^{*}$} & \multirow{3}{*}{0.102} \\
\hline & Experimental & $\begin{array}{c}46.60 \pm 16.67 \\
(37.75-54.35)\end{array}$ & $\begin{array}{c}26.55 \pm 14.78 \\
(21.66-36.44)\end{array}$ & & \\
\hline & Control & $\begin{array}{c}32.10 \pm 16.16 \\
(24.54-39.66)\end{array}$ & $\begin{array}{c}24.60 \pm 15.27 \\
(17.46-31.74)\end{array}$ & & \\
\hline KIN & Experimental & $\begin{array}{c}40.55 \pm 5.61 \\
(37.92-43.18)\end{array}$ & $\begin{array}{c}40.78 \pm 4.86 \\
(38.61-43.39)\end{array}$ & \multirow[t]{2}{*}{0.825} & \multirow[t]{2}{*}{0.001} \\
\hline \multirow{3}{*}{ BME (s) } & Control & $\begin{array}{c}42.10 \pm 4.23 \\
(40.12-44.07)\end{array}$ & $\begin{array}{c}41.70 \pm 4.17 \\
(39.94-43.86)\end{array}$ & & \\
\hline & Experimental & $\begin{array}{c}11.05 \pm 8.39 \\
(7.12-14.98)\end{array}$ & $\begin{array}{l}14.30 \pm 19.24 \\
(9.98-18.82)\end{array}$ & \multirow[t]{2}{*}{0.853} & \multirow[t]{2}{*}{0.001} \\
\hline & Control & $\begin{array}{l}10.85 \pm 9.79 \\
(6.27-15.43)\end{array}$ & $\begin{array}{l}13.90 \pm 11.63 \\
(8.46-19.35)\end{array}$ & & \\
\hline
\end{tabular}

*denotes significance at $\mathrm{p} \leq 0.05$

PI - pain intensity scores, DI - disability index scores, KIN- kinesiophobia scores, BME - back muscle endurance

\section{Discussion}

This study was carried out to compare the effects of lumbar stabilisation exercise plus conventional physiotherapy and conventional physiotherapy alone on pain intensity, disability, kinesiophobia and back muscle endurance among individuals with chronic low back pain.The results suggest that lumbar stabilization exercise plus conventional therapy and conventional therapy in isolation are similar in their effects on pain, kinesiophobia and back muscle endurance. The combined treatment however appears more beneficial in terms of reduced disability.

There was a significant improvement in pain intensity, disability and back muscle endurance but not in kinesiophobia after 8 weeks of treatment in both groups. Reduction in pain intensity and disability was not surprising, since all participants received infrared radiation and Transcutaneous electrical nerve stimulation (TENS) which have been reported as being efficacious in relieving chronic low back pain and associated disability. ${ }^{38,39}$ Moreover, both groups also received back education and were given an instructional manual for follow-up at home. 
This suggests participants in both groups performed or avoided some activities at home during the course of the study which in turn was beneficial in terms of reduced pain and disability. Similar beneficial effects of back education have been reported among Nigerians with CLBP. ${ }^{40,41}$ The findings of previous investigators ${ }^{30,42}$ regarding decreased pain and disability following LSE is also consistent with results of this study. The improvement in back muscle endurance for both groups may be attributed to pain relief. A significant inverse correlation was reported for pain and back muscle endurance in patients with mechanical LBP, ${ }^{18}$ although studies on the efficacy of LSE on back muscle endurance are rather scarce.

The two treatment regimens did not have significant effects on kinesiophobia. There are no available studies that have looked at this but the finding may be due to ambiguity in the construct of some items of the Tampa Scale of Kinesiophobia Questionnaire. However, this needs to be investigated further. Moreover, participants in both groups still had appreciable levels of pain (experimental: $3.48 \pm 1.09$; control: $2.96 \pm 1.13$ ) at the end of the $8^{\text {th }}$ week which could have made the participants fearful of movement or re-injury. This is despite the fact that there were significant reductions in both groups compared to baseline.

Reduction in pain and consequent improvements in function following lumbar stabilisation exercise have been attributed to improved activation patterns of trunk muscles and relieved lumbar pain and incapacity through trunk muscle contraction. ${ }^{21,43}$ Weakness and lack of motor control of deep trunk muscles, such as the lumbar multifidus (LM) and transversus abdominis ( $\operatorname{Tr} \mathrm{A})$ muscles are consistent with LBP. ${ }^{5,44}$ Individuals with chronic LBP are predisposed to delayed recruitment and insufficient control of the $\operatorname{TrA} \cdot{ }^{45,46}$ It was opined that the emergence of biomechanical, neurophysiological, and histochemical dysfunctions in the LM of patients with LBP, such as atrophy occurs in the ipsilateral painful level. ${ }^{47}$ Reduction in the size of the MF was also suggested deteriorating lumbar stability and cause painful structures or new injuries, thereby inducing pain and functional disabilities. ${ }^{48}$ Deficits of MF causing low back pain and disability as well the resultant instability in local regions as would not be reversed naturally and that is a crucial factor for increased recurrence rate of LBP. ${ }^{5}$ Spinal instability induces pain, reduces endurance and flexibility, and restricts the range of motion of the lumbar joints and all contributes to disability. ${ }^{49}$ Stabilisation exercises are hence indicated for the prevention of the recurrence of pain induced by damage to the musculoskeletal system and consequent improvement of functional activities. ${ }^{50}$ The systematic review by Hauggaard and Persson ${ }^{24}$ also revealed moderate evidence of improved disability and or pain level following specific spinal stabilisation exercises.

The superiority of LSE programme over the conventional treatment in terms of reduced disability is promising. Participants in the control group did not receive any supervised active exercises like their experimental counterparts who underwent a wellstructured and supervised exercise programme. The finding is however not consistent with the work of Cairns et al ${ }^{51}$ which showed no difference in the disability mean changes of individuals with recurrent LBP who had specific spinal stabilisation exercises and conventional physiotherapy. Oswestry Disability Questionnaire (ODQ) was the measuring tool in this study while Cairns and colleagues used Roland Morris Disabilty Questionnaire (RMDQ).Differences in the construct of both instruments might account for the variation in findings. There are also differences relating to frequency and intensity of exercise as well as sample size between both studies, Koumantakis et al ${ }^{42}$ also found that general exercises produced significantly greater reduction in disability than general exercises plus spinal stabilisation exercises. There are also differences relating to measuring instruments (ODQ vs RMDQ) and sample size (40 vs 55) between the present study and the work of Koumantakis et $a 1 .{ }^{42}$ Furthermore, the present study involved participants with LBP of different subgroups whereas the aforementioned investigators involved patients with LBP of homogeneous aetiology.

\section{Limitations of study}

A major limitation of this study was lack of randomization in assigning participants into groups. This would have ensured an even distribution of population characteristics between the groups. The significant difference in disability index observed between the groups at baseline was however adjusted for in data analysis.

\section{Conclusion/Recommendation}

Augmenting conventional Physiotherapy with lumbar stabilisation exercises achieved better reduction in disability than conventional Physiotherapy alone.

Future studies should improve on sample size for improvements in external validity. Further, 
Ademola O. Abass, Abiola R. Alli, Oladapo M. Olagbegi, Candice J. Christie4and Samuel O. Bolarinde

conducting a randomized controlled trial design may also strengthen the internal validity of the study. Designing a follow-up phase with the intent of observing the incidence of recurrence of low back pain may shed more light on the sustainability of the effects of LSE in the management of NSCLBP.

Acknowledgement: We acknowledge and thank all persons who dedicated their time and participated in this study.
Conflict of interest: None declared

\section{Funding/support}

This project was fully funded by the authors.

\section{Author's Contributions}

A.O.A and A.R.A. conceptualized the study and were involved in data acquisition; O.O.M. performed data analysis and drafted the manuscript while CJC and S.O.B. critically revised the manuscript. All authors read and approved the final version of the manuscript.

\section{References:}

1. May SJ. Patient satisfaction with management of back pain (Part 1). Physiother 2001; 187: 4-9.

2. Ehrlich GE. Low back pain. Bulletin of the World Health Organization 2003; 81 (9).

3. Omokhodion FO. Low back pain in a rural community in South West Nigeria. West Afri J Med 2002; 21, 87-90.

4. Manek NJ, MacGregor AJ. Epidemiology of back disorders: prevalence, risk factors, and prognosis. Curr Opin Rheumatol 2005; 17:134-140.

5. Hides JA, Richardson CA, Jull GA. Multifidus muscle recovery is not automatic after resolution of acute, firstepisode low back pain. Spine 1996;21:27.

6. Waddell G. Back pain revolution 2nd ed. 2004. Edinburgh; Churchill Livingstone. pg 8

7. Odole AC, Akinpelu AA, Adekanla BA, Obisanya OB. The Economic burden of low back pain on patients seen on outpatient physiotherapy clinics of secondary and tertiary health institutions in Ibadan. J Nigeria Society Physiother 2011; 18\&19: 43-48.

8. Omokhodion FO, Sanya AO. Risk factors for low back pain in office workers. J Occup Med 2003; 53:287-289.

9. Battié MC, May L. Physical and occupational therapy assessment approaches. In Turk, DC and Melzack R. (Eds.), Handbook of pain assessment ( $2^{\text {nd }}$ ed.) 2001. NewYork, Guilford Press.

10. Fritz JM, George SZ, Delitto A. The role of fearavoidance beliefs in acute low back pain: relationship with current and future disability and work status. Pain 2001; 94:7-15.

11. Vlaeyen JWS, Kole-Snijders AMJ, Rotteveel AM. The role of fear of movement/ (re) injury in pain disability. $J$ Occup Rehabil 1995; 5:235-52

1. Picavet HS, Vlaeyen JW, Schouten JS. Pain catastrophizing and kinesiophobia: predictors of chronic low back pain. $\mathrm{Am}$ J Epidemiol 2002; 156(11):1028-1034

12. Kori S, Miller R, Todd D. Kinesiophobia: A new view of chronic low pain behaviour. Pain Manag 1990; 2 :35-43.

13. Calliet R. Low Back Pain Syndromes 3rd ed. 1981. Philadelphia: F.A. Davis

14. 15. Hultman G, Nordin M, Saraste H, Ohlsen H. Body composition, endurance, strength, cross-sectional area and density of erector spine in men with and without low back pain. J Spinal Disord 1993; 6: 114-123.

15. Wilder, DG, Aleksiev, AR. Muscle response to sudden load: a tool to evaluate fatigue and rehabilitation. Spine 1996; 21 (22): 2628-39

16. Biering-Sorensen F. Physical measurements as risk indicators for low back trouble over a one year period. Spine 1984; 9:106-119.

17. Mbada CE, Ayanniyi A, Ogunlade SO. Relationship between Pain Intensity, Activity Limitation, Static and Dynamic Back Muscles Endurance in Patients with Nonspecific Long term Low-back Pain. J Nigeria Society Physiother 2011; 18 \& 19: 14-21.

18. Quinn S, Bird S. Influence of saddle type upon the incidence of lower back pain in equestrian riders. $\mathrm{Br} \mathrm{J}$ Sports Med 1996; 30:140-4.

19. Alaranta H, Hurri, H, Heliovaara M, Soukka A, Harju R. Non-dynamometric trunk performance tests: Reliability and normative data. Scan J Rehabil Med 2006; 26: 211-215

20. Kavcic N, Grenier S, McGill SM. Quantifying tissue loads and spine stability while performing commonly prescribed low back stabilization exercises. Spine 2004; 29 (20): 2319-2329.

21. Goldby LJ, Moore AP, Doust J, Trew ME. A randomized controlled trial investigating the efficiency of musculoskeletal physiotherapy on chronic low back 
Effects of an eight-week lumbar stabilization exercise programme on selected variables of patients with chronic low back pain

disorder. Spine 2006; 31(10):1083-1093

22. Nachemson A. Lumbar spine instability: a critical update and symposium summary. Spine 1985; 10:290-1

23. Hauggaard A, Persson A. Specific spinal stabilisation exercises in patients with low back pain- a systematic review. Phys Ther Rev; 2007;12:223-248

24. Panjabi MM. The stabilizing system of the spine. Part II. Neutral zone and instability hypothesis. J Spinal Disord 1992; 5(4): 390-7.

25. Richardson C, Jull G. Muscle control - pain control. What exercises would you prescribe? Man Ther 1995; 1:2-10

26. Kim S, Kimand H, Chung J. Effects of spinal stabilization exercise on the cross-sectional areas of the lumbar multifidus and psoas major muscles, pain intensity, and lumbar muscle strength of patients with degenerative disc disease. J Phys Ther Sci 2014; 26(4): 579-582.

27. O'Sullivan P, Twomey L Allison G. Dysfunction of the neuromuscular system in the presence of low back pain - implications for physical therapy management. J Man Manip Ther1997; 5: 20-6

28. Standaert, JC, Weinstein, SM, Rumpeltes, J. Evidenceinformed management of chronic low back pain with lumbar stabilization exercises. Spine 2008; 18. 2:114-120

29. França, FR, Burke, TN, Caffaro, RR, Ramos, LA, Marques, AP. Effects of muscular stretching and segmental stabilization on functional disability and pain in patients with chronic low back pain: a randomized, controlled trial. J Manipulative PhysiolTher 2012; 35(4):279-285.

30. Kumar, SP. Efficacy of segmental stabilization exercise for lumbar segmental instability in patients with mechanical low back pain: A randomized placebo controlled crossover study. N Am J Med Sci 2011; 3:485-461.

31. Odebiyi DO. How to avoid back pain at work and rest: a handbook of the Nigerian back school. 2004 Lagos. Crowntex Printing Press-Publishers.

32. Gould D, Kelly D, Goldstone L, Gammon J. Examining the validity of pressure ulcer risk assessment scales: developing and using illustrated patient simulations to collect the data. J Clin Nurs 2001; 10(5): 697-706

33. Back M, Cider, A, Herlitz, J, Lunder, M. Physiotherapy Research Report 2011; 97 supplement S1, RAi: E106-107.

34. Fairbank JCT, Pysnent, PB. The Oswestry disability Index. Spine 2000; 25 (22): 2940-2953.

35. McIntosh G, Wilson L, Affieck F, Hall H. Trunk and lower extremity muscle endurance: normative data for adults. J Rehabili Outcome Measure 1998; 20-39

36. Cohen, J. Statistical Power Analysis for the Behavioral Sciences. 2nd ed.1988. New York. Academic Press: 55.

2. Gale GD, Rothbart PJ, Li Y. Infrared therapy for chronic low back pain: A randomized, controlled trial. Pain Res Manag 2006 ;11(3): 193-196.
3. Facci LM, Nowotny JP, TormemF, Trevisani VFM. Effects of transcutaneous electrical nerve stimulation (TENS) and interferential currents (IFC) in patients with nonspecific chronic low back pain: randomized clinical trial.Sao Paulo Med J2011; 129 (4):206-16 http://dx.doi. org/10.1590/S1516 31802011000400003

37. Akinpelu A.O, Odebiyi D.O 2004. Nigerian back school model; development and effect on industrial workers knowledge of back pain and care. Afr J Med MedSci 33:201-5

4. Ayanniyi O, Ige O.G. Back care education on peasant farmers suffering from chronic mechanical low back pain. J ExpIntegr Med. 2015:4 doi:10.5455/jeim.231115.or.142

38. Koumantakis G, Watson P, Oldham J. Trunk muscle stabilization training plus general exercise versus general exercise only: randomized controlled trial of patients with recurrent low back pain. Phys Ther 2005; 85:209-25

39. Goldby L. Exercises for low back pain Br J Ther Rehabil. 1996; 3:612-6.

40. 44. Richardson C, Hodges P, Hides J. Therapeutic exercise for lumbopelvic stabilisation. A motor control approach for the treatment and prevention of low back pain. 2nd ed. Queensland, Australia: Churchill Livingstone. 2004

41. 45. Ferreira P.H, Ferreira M.L, Maher C.G, Refshauge K, Herbert R, Hodges P.W. Changes in recruitment of transverses abdominis correlate with disability in people with chronic low back pain. Br J Sports Med 2010;44:1166-72.

42. 46. Hodges, P.W, Richardson C.A. Inefficient muscular stabilisation of the lumbar spine associated with low back pain: a motor control evaluation of transverses abdominis. Spine 1996; 21:2640-50.

43. 47. MacDonald, D.A., Moseley, G.L. and Hodges, P.W. 2006. The lumbar multifidus: Does the evidence support clinical beliefs? Man Ther 1996;11(4): 254-263.

44. 48. Beneck, G.J. and Kulig, K. Multifidus atrophy is localized and bilateral in active persons with chronic unilateral low back pain. Arch Phys Med Rehabil 2012;93(2), 300-306.

45. 49. Gill, K.P., Krag, M.H., Johnson, G.B., Haugh, L.D. and Pope, M.H. Repeatability of four clinical methods for assessment of lumbar spinal motion. Spine 1988 ;13(1), 50-53.

46. 50. Jette, A.M. Outcomes research: shifting the dominant research paradigm in physical therapy. Phys Ther 1995 ;75(11), 965- 970.

47. 51. Cairns M, Foster N, Wright C. Randomized controlled trial of specific spinal stabilization exercises and conventional physiotherapy for recurrent low back pain. Spine 2006; 31:E670-81. 